\title{
22 DISCREPANCY BETWEEN THE LEGALITY OF THE DEATH PENALTY AND AFRICAN RELIGIOUS HERITAGE IN ZIMBABWE
}

\section{Tobias Marevesa ${ }^{1}$ Fortune Sibanda ${ }^{2}$}

\begin{abstract}
INTRODUCTION
From time beyond reckoning, the death penalty has been perceived in ambivalence. On the one hand, some people regard the death penalty as inhuman, anachronistic, wild and a barbaric way of instilling discipline that must be abolished. In addition, some consider this law as "un-African" and a legacy of western colonial rule. ${ }^{3}$ On the other hand, capital punishment also commands support as a deterrent to potential criminals and in dealing with notorious people in extenuating situations. In Zimbabwe, the legal regime regarding the death penalty is relatively fluid, and this has created uncertainty, confusion and a dilemma amongst citizens. ${ }^{4}$ Whereas civic groups, governments and legal experts have grappled with the issue of the death penalty for many years, this chapter uses the religious lens to provide an Afro-centric reading of the African religious heritage on the death penalty in Zimbabwe. ${ }^{5}$

This chapter utilises the Afrocentric paradigm as a theoretical framework to understand the discrepancy between the legality of the death penalty and African religious heritage in Zimbabwe. Afrocentricity was made popular by
\end{abstract}

1 Tobias Marevesa is a PhD candidate with North-West University, South Africa. He is a lecturer in Religious Studies, Department of Philosophy and Religious Studies, Great Zimbabwe University, Masvingo.

2 Fortune Sibanda received his PhD from the University of Zimbabwe in 2015. He is a lecturer in Religious Studies, Department of Philosophy and Religious Studies, Great Zimbabwe University, Masvingo.

3 Agere H. 2016. "Death Penalty Raises Stink", The Sunday Mail Extra, 24 January:E1. See also 2016. "Death Penalty is, in fact, a Flagrant Violation of the Right to Life and Dignity", The Herald, 23 February.

4 Agere, "Death Penalty Raises Stink".

5 See Verstraelen FJ. 1998. Zimbabwean Realities and Christian Responses. Gweru: Mambo Press. See also Parrinder G. 1969. Africa's Three Religions. London: Sheldon Press, whose book title is crafted to reflect coverage of African Indigenous Religion, Christianity and Islam on the basis of their long presence on the African continent. Thus, all the three religions constitute "African religious heritage" and it is the sense in which it is used in this chapter. The phrase "African religious heritage" also affirms the spirituality and religiosity of Africans that define them as a people in the sense in which Mbiti JS (1969. African Religions and Philosophy. Oxford: Heinemann Books, 2) understood it when he asserted that "Africans are notoriously religious." 
African scholars such as Molefi Kete Asante and Maulana Karenga, ${ }^{6}$ who are leading scholars and advocates of the Afrocentric genre. The emergence of Afrocentricity came as a reaction to Eurocentric ideology, which universalised European aspects of culture, communication, philosophy, education, rhetoric, linguistics, history, psychology and anthropology. ${ }^{7}$ The legal community in Zimbabwe is also steeped in western ideologies, as reference is still made to the Roman-Dutch law and English common law within the legal system of the country to this day. Therefore, an Afrocentric approach to the Zimbabwean legal system would accommodate African traditional law, alongside the views of Christianity and Islam, rather than merely depending on the westerninfluenced legal systems to deal with issues of capital punishment.

The Afrocentric paradigm has the merit of being both a corrective and a critique. As a corrective, Afrocentricity counters the European meta-paradigm, which denied the agency and action of African people in legal matters. Under colonial rule and in some postcolonial contexts, African customary law and beliefs on matters of human life, death and the hereafter, particularly in the context of phenomena such as the ngozi (avenging spirits), there was a tendency to ignore and deny the efficacy of these customary beliefs. One of the present authors (Sibanda), an Afrocentric scholar of the history and phenomenology of religion, asserts that the Eurocentric approach to African beliefs in ngozi minimised them, at worst, as mere nonexistent superstition and, at best, as evil spirits, but those who murdered innocent people were often tormented by avenging spirits in cases usually settled through restitution mediated by traditional courts, thereby proving the vitality of African traditional law in this context. ${ }^{8}$ This shows the relevance of the Afrocentric theory in countering the Eurocentric predominance in the Zimbabwean legal system. As a critique, the Afrocentric paradigm can sensitise people towards realising that they are their own liberators or oppressors in the context of the issue of the death penalty, given that the Constitution of Zimbabwe should be fair and just to all citizens. Therefore, Afrocentric theory is vital to this study in light of the discrepancy between the legality of the death penalty and African religious heritage in Zimbabwe.

This chapter collects data from interviews with elders, traditional leaders, church leaders, members of the Lemba ${ }^{9}$ Islamic community and legal practitioners.

6 Adeleke T. 2009. Case Against Afrocentricism. Jackson, MS: University Press of Mississippi, 9.

7 Asante MK. 1998. The Afrocentric Idea. Philadelphia: Temple University Press, 19.

8 Sibanda F. 2016. "Avenging Spirits and the Vitality of African Traditional Law, Customs and Religion in Contemporary Zimbabwe", in Coertzen P, Green MC and Hansen L (eds). Religious Freedom and Religious Pluralism in Africa: Prospects and Limitations. Stellenbosch: African Sun Media, 347.

9 In Zimbabwe, the Lemba/Varemba people belong to the Karanga ethnic group and are mainly found in Mberengwa District, Midlands province, as well as in Gutu and Masvingo Districts, Masvingo province, in Zimbabwe. There has been extensive work undertaken on the Lemba communities. They seem to be distant descendants of a mixed population of Africans, Arabs and others. 
Data was also gathered through documentary analysis of print and electronic media covering issues of capital punishment in Zimbabwe. The study also combined insights from the historical, sociological and phenomenological approaches to describe and analyse the data. According to Fredrick J Streng, a historian of religion, the history of religions systematically organises and classifies religious material. ${ }^{10}$ Using the historical approach in this study had the merit of tracing the origins and background capital punishment in Zimbabwe and beyond within African Indigenous Religion (AIR), African Christianity and Lemba Islam. In addition, previous and current statistical records of the inmates on death row or whose verdicts were transformed to life in prison are also explored through the historical approach.

Sociology of religion is about how religion affects people and how people are affected by religion. ${ }^{11}$ The method focuses on human relationships and interactions in society. Through sociological method, one can explore issues in relation to religion and law, class, gender, economics, change and other aspects of society. Therefore, a socio-historical approach from the history and sociology of religion may provide a favourable platform for understanding the legality of the death penalty in Zimbabwe, given that religious phenomena like existing legal institutions, are socially and historically conditioned. As a method that seeks to promote the insider perspective, the phenomenology of religion provides the study with tools of analysing the views of participants by using epoche (bracketing), empathy, descriptive accuracy and eidetic intuition, through which the meaning of religion can be approximated. ${ }^{12}$ The phenomenological method emphasises the need to avoid terms like "superstition" and "preliterate" with reference to African beliefs and practices, as well as customary

By the sixteenth century, they were engaged in Islamic, some Abrahamic, and local (Zimbabwean) ritual practices. Some of the Lemba are Muslims, whilst others are Jewish in their religious orientation. The Lemba have a syncretic tendency in which they mix Islamic and African traditional practices. A lot of debate has focused on their Muslim or Jewish character. It has been observed that the "Lemba did not retain the 'Islamic' identity of their ancestors, but their distinctive, syncretic forms of circumcision, burial and ritual slaughter perpetuate a sense of 'difference' from surrounding populations", Shaw R and Stewart C. 1994. "Introduction: Problematising Syncretism", in Stewart C and Shaw R (eds). Syncretism/Anti-Syncretism: The Politics of Religious Synthesis. London: Routledge, 16. The Zimbabwean scholar Ephraim Mandivenga has argued that the Lemba was a product of earlier Muslim activities enforced through "re-Islamisation". See Mandivenga E. 1989. "The History and 'Re-Conversion' of the Varemba of Zimbabwe", Journal of Religion in Africa 19(2):98-124. See also Chitando E. 2011. "VaJudha (African Jews) in Harare: Expressing Contested Identities in Tight Spaces", African Studies 64(2):137.

10 Streng FJ. 1985. Understanding Religious Life. Belmony: Wadsworth Publishing Company, 220.

11 Bourdillon MFC. 1990. Religion and Society: A Text for Africa. Gweru: Mambo Press.

12 See, for example, Chitando E. 1998. "The Phenomenological Method in a Zimbabwean Context: To Liberate or to Oppress?", Zambezia 25(1):99-114. In this article, Chitando suggests that, notwithstanding its weaknesses, the phenomenology of religion is ideal for studying African Indigenous Religion. 
law. Although the history of religions and phenomenology of religion share an anti-reductionist stance towards religious and social phenomena as sui generis, thereby promoting the uniqueness of religion, this is in contrast to the sociology of religion, which "explains away" social and religious phenomena. Therefore, a corroboration of the three approaches in the context of the death penalty is ideal for the chapter, since the weaknesses of one method can be covered by the strengths of other methods.

This chapter focuses on the discrepancy between the legal basis of the death penalty and how it is perceived from the perspectives of African religious heritage in Zimbabwe. It employs a broad understanding of "African religious heritage" to refer to the trilogy of African Indigenous Religion (AIR), African Christian tradition and Lemba Islam. By "heritage", this chapter encompasses the religious, cultural, legal and historical traditions and how they formulate religious identities and societies in contemporary Africa. The chapter posits that capital punishment does not augur well with human rights and religious norms within AIR, African Christianity and Lemba Islam. In other words, there is a discrepancy between the legality of the death penalty and African religious heritage, as it is experienced in Zimbabwe. The chapter further argues that although the Constitution of Zimbabwe currently still provides for the death penalty, the existence of a moratorium ${ }^{13}$ is a hopeful stance for an eventual abolitionist position that would be commensurate to African religious heritage.

\section{THE CONCEPTION OF DEATH IN THE AFRICAN WORLD VIEW}

The overarching influence of African cosmology goes beyond practitioners of African Indigenous Religion (AIR) to include African Christians and African Muslims, particularly on matters of death and the hereafter. It is from this premise, that this section addresses the conception of death in the African worldview. Africans, including the Shona of Zimbabwe, believe that humanity was created by the Supreme Being, Mwari, who controls life and death. No one, therefore, has the right to take anyone's life except the Creator. Yet, they believe that in society, there are good and bad spirits, with some people harming others through anti-social practices of witchcraft and sorcery. They also believe in life after death, holding that "after the physical death of the body (nyama), the soul (mweya) continues to live."14 Thus, there is both the physical and the spiritual existence. According to Canaan S Banana, an African scholar and theologian, "Life is an endless enterprise. Death is not death; it is a vehicle from the ontology of visible beings to the ontology of invisible beings. Death is part of life, it is a

13 Moratorium is a constitutional provision in which the state suspends executions as a sort of "halfway measure" between abolition and retention of applying the death penalty. Legally, such a state would still have the death penalty, though probably with a weak resolve. However, the problem is that the state can resume executions at any time.

14 Sibanda, "Avenging Spirits and the Vitality of African Traditional Law", 350. 
gateway to life in the here-after."15 African people perceive life and time in a cyclic fashion, which contrasts the linear western conception of time and life. From this understanding, it is held that "a person exists from an 'it' at birth, without a name, and is expected to live to a ripe old age before passing on to the next spiritual life after death, where the individual eventually develops into an 'it' - a nameless dead". ${ }^{16}$

Among the Shona, the dead are said to have a greater and more mysterious power-force as compared to that of the living, making "death a graduation and a gravitation into a new and higher life" ${ }^{17}$ The immortality of the spirit is summed up by the Shona saying that claims: "Chinoora inyama, mweya hauori" (what perishes is the flesh, but the spirit is immortal). ${ }^{18}$ The saying above contains the traditional beliefs on death and the hereafter, vital to the study of the death through capital punishment and the impact of ngozi spirit to the hangman who effects the death on behalf of the government. Ending life through the death penalty may suggest that a person is guilty of a serious crime deserving a moral sanction by society. In such a scenario, performing death rituals like kurova guva (to beat the grave) ceremony, which brings back the spirit of the dead home and domesticates it, ${ }^{19}$ might be impossible. This is because the state, by law, would not surrender the copse of the hanged person to the family members for a decent burial. In this way, without a proper burial of the body, there is no grave to speak of and there can be no death rituals. The hanged person is therefore likely to be disqualified from the status of being a mudzimu (ancestor), where s/he spiritually joins other "living dead" as "guardians of the family affairs, traditions, ethics and activities". ${ }^{20}$ Although the power of those who die through capital punishment cannot be underrated, since they can also come back as an avenging spirit to the hangman until they are fully compensated, the question that remains is how justified this move is in light of existing statutes vis-à-vis the abolitionist position attributed to African religious heritage in Zimbabwe.

\section{THE ZIMBABWEAN DEATH PENALTY: A HISTORICAL OVERVIEW}

In all societies, the death penalty has a long history of controversy for being employed to end human life. While not all crimes merit the contentious death penalty, cases of attempted murder, murder, conspiracy, treason, rape, attempted rape, aggravated robbery, felony murder, among other offences,

15 Banana CS. 1991. Come and Share: An Introduction to Christian Theology. Gweru: Mambo Press, 27.

16 Sibanda, "Avenging Spirits and the Vitality of African Traditional Law", 350.

17 Banana, Come and Share, 28.

18 Sibanda, "Avenging Spirits and the Vitality of African Traditional Law", 350.

19 Banana, Come and Share, 30.

20 Banana, Come and Share, 32. 
top the list. ${ }^{21}$ In colonial Africa, the death penalty was a prominent feature of legislation for political, religious and social reasons. ${ }^{22}$ This has spilled over into some postcolonial African countries. ${ }^{23}$ Amnesty International has been working towards ending executions since 1977, when only sixteen countries had abolished the death penalty in law or practice. ${ }^{24}$ Today, about two thirds of the countries worldwide have abolished capital punishment. ${ }^{25}$ Paradoxically, some countries, like the United States of America, who are key players in the advocacy for human rights through abolishing the death penalty, are complicit in the sentencing and execution of people. ${ }^{26}$ The American "criminal justice system" is punctuated by a language of justice and injustice, a discourse in which questions of human rights and democratic legitimacy come to the fore, ${ }^{27}$ marred by the persistence of capital punishment in a globalised world.

In postcolonial Zimbabwe, for instance, the death sentence has been restricted to murder and treason since $1992,{ }^{28}$ and it has been retained in the Constitution (Amendment No. 20 of 2013), where in Part 2 under Fundamental Human Rights and Freedoms, Section 48, on the "Right to life", says in subsection (1) says: "Every person has the right to life." However, this fundamental right to life is immediately compromised when, in subsection (2), the death penalty is

21 Agere, "Death Penalty Raises a Stink".

22 African Commission on Human and Peoples' Rights (ACHPR). 2011. Study on the Question of the Death Penalty in Africa. Banjul, The Gambia: Baobab Printers, 25.

Online at: http://www.achpr.org/files/news/2012/04/d46/study_question_ deathpenalty_africa_2012_eng.pdf

23 Examples of these postcolonial African countries that still have the death penalty are Benin, Burkina Faso, Gambia, Ghana, Nigeria, Liberia, Mali, Cameroon, Chad, Democratic Republic of Congo, Equatorial Guinea, Eritrea, Ethiopia, Kenya, South Sudan, Sudan, Somalia, Tanzania, Uganda, Botswana, Lesotho, Madagascar, Malawi, Swaziland, Zambia, Zimbabwe, Algeria, Egypt, Libya, Morocco and Tunisia. These states are de facto abolitionist - that is, they have not legally proscribed the death penalty but decline to authorise the execution of those sentenced to death. They have frozen or put on hold all executions of condemned prisoners. In other words, they have put in place a moratorium. See ACHPR, Study on the Question of the Death Penalty in Africa, 28, 29, 47.

24 Hersher R. 2016. "Death Sentences and Executions are Down, But Voters Still Support Death Penalty Laws", NPR.org, 21 December.

25 Erickson M. 2016. "Death Penalty". Amnesty International Online at: https:// www.amenesty.org/en/what-we-do/death-penalty/. Today, Europe is a death penalty-free zone.

26 Hersher,"Death Sentences and Executions are Down, But Voters Still Support Death Penalty Laws". Ideally, the death penalty is still legal in 37 of the 50 states in the United States. For instance, it has been recorded that out of 30 people who were sentenced to death, 20 were executed in the U.S. in 2016 alone.

27 Isaac JC. 2015. "The American Politics of Policing and Incarceration", Perspectives on Politics: A Political Science Public Sphere 13(3):609.

28 Novak A. 2014. "Capital Sentencing Discretion in Southern Africa: A Human Rights Perspective on the Doctrine of Extenuating Circumstances in Death Penalty Cases", African Human Rights Law Journal 14(1):32. 
announced as applicable in specified offences. ${ }^{29}$ The persistence of this statute is indicated by the existence of over one hundred inmates who are currently on the death row. ${ }^{30}$ If these people on the death row continue to be "marked for death", this shows an existing historical contradiction and anomaly associated with the issue of the death penalty in Zimbabwe, which can be illustrated through reference to different religious traditions constituting African religious heritage in Zimbabwe.

\section{AFRICAN RELIGIOUS HERITAGE AND THE ENIGMA OF THE DEATH PENALTY IN ZIMBABWE}

As intimated earlier, African religious heritage is used in the study underlying this chapter to refer to what the distinguished scholar of comparative religion, Geoffrey Parrinder, described as "Africa's three religions", namely, African Traditional Religion (ATR), Christianity and Islam. The longstanding history of these traditions in Africa qualifies them to constitute African religious heritage. None of these religions can be viewed in monolithic terms in the African religious context. Therefore, this section provides an overview of each of these traditions to demonstrate the discrepancy between the death penalty and the historical and social realities in the religious realm.

\section{African traditional religion perspective}

The African traditional perspective is illustrated through reference to Shona traditional religion. There is a claim that, historically, under the Munhumutapa Empire, ${ }^{31}$ the Shona did not have the death penalty. ${ }^{32}$ Although it might be true for Shona societies to say that the death penalty was nonexistent in precolonial Africa, there is also ample evidence to the contrary concerning its existence in

29 Constitution of Zimbabwe (Amendment No. 20 of 2013). Section 48(2) states: "A law may permit the death penalty to be imposed only on a person convicted of murder committed in aggravating circumstances, and - (a) the law must permit the court a discretion whether or not to impose the penalty; (b) the penalty may be carried out only in accordance with a final judgment of a competent court; (c) the penalty must not be imposed on a person - (i) who was less than twentyone years when the offence was committed; or (ii) who is more than seventy years old; (d) the penalty must not be imposed or carried out on a woman; and (e) the person sentenced must have a right to seek pardon or commutation of the penalty from the President." See also 2016. "Zimbabwe: Death Penalty Violates Human Rights", Zimbabwe Standard, 25 September.

30 Agere, "Death Penalty Raises a Stink".

31 This is a precolonial empire set by the Shona people. At the height of its rule, the empire stretched from the western parts of present day Zimbabwe to Mozambique in the East. See Bourdillon MFC. 1987. The Shona Peoples. Gweru: Mambo Press for a map of Munhumutapa Empire.

32 Maodza T. 2016. "Capital Punishment Archaic: VP Mnangagwa", The Herald. 25 February:2. 
other African communities. ${ }^{33}$ In precolonial Zimbabwe, the Shona traditional or customary law was an oral law enforced by kings or chiefs and indunas (chief's advisors). Its unwritten form presented challenges of ascertaining its exact content and application. However, in Shona society, it appeared to be the case that the death penalty was never applied, unlike the situation in Zimbabwe today. According to Shona tradition, a person guilty of a capital offence was not necessarily executed, but alternative methods of dealing with the criminals were employed. In cases of crimes such as murder, the traditional kings or chiefs would order the perpetrator to compensate by paying "blood money" or a herd of cattle to the victim's family. "Blood money" was paid to assuage the anger of the victim's family for loss suffered and to promote peace and reconciliation. ${ }^{34}$

If literary works could be read as Shona history, it can be argued that Francis D Hodzongi's Mhosva Inoripwa ${ }^{35}$ and Father Emmanuel F Ribeiro's Muchadura ${ }^{36}$ both Shona fiction novels - are instructive on how Shona society tried to instil moral uprightness, such that people would avoid killing each other, lest they suffer from the consequences of the ngozi spirits. In addition, Shona society could banish the offender from the village permanently or temporarily. In the case of banishment, the guilty person was exiled for a stated period of time and upon return was expected to perform sacrifice that was a form of restitution sanctioned by the elders. It can be noted that among the Shona people, just as in some other African communities, "the execution of criminals for serious crimes must not be confused with cases of deprivation of life for reasons other than a penalty crime". ${ }^{37}$ Therefore, the Shona traditional religion can be regarded as a system that sought to preserve life at all costs by avoiding retributive justice. This is in tandem with the observation that some African communities, in cases of murder, "saw no point in sacrificing a second life for one already lost because that meant causing the loss of another breadwinner and creating in the process more orphans and widows/widowers". ${ }^{38}$ So, on the basis of the African

33 For instance, scholars' writings on African law refer to the Zulu kingdom in South Africa where adultery with any of the chief's wives attracted a death penalty. In such contexts, the methods of execution included decapitation, spearing to death, administration of poison, and burial of people alive. See, for example, ACHPR, Study on the Question of the Death Penalty in Africa, 23.

34 ACHPR, Study on the Question of the Death Penalty in Africa, 9, 25.

35 Hodzongi FD. 1981. Mhosva Inoripwa. Harare: Longman.

36 Ribeiro EF. 1977. Muchadura. Gweru: Mambo Press.

37 ACHPR, Study on the Question of the Death Penalty in Africa, 24. For instance, the Shona communities had practices such as 'ritual' murder, killing at birth twins or a child born with teeth, a person guilty of practising witchcraft, death from trials by ordeal, among others.

38 ACHPR, Study on the Question of the Death Penalty in Africa, 25. Once again, reference to literary works from a historical perspective shows that Shona fiction novels, particularly Nobert Mafumhe Mutasa's Mapatya [Twins] (Salisbury: Longman Rhodesia, 1978) and Ignatius M Zvarevashe's Gonawapotera [a deep sacred pool where the ostracised people were thrown to die] (Salisbury: College Press, 1978) are instructive on demonstrating how Shona society eliminated some of its people through death for various reasons, such as ritual murder of 
philosophy of ubuntu (humanness), the Shona did not practise an eye for an eye principle, because it would make the world blind. This shows that there is a discrepancy between the death penalty, as it is practised today, and Shona traditional religion in Zimbabwe.

\section{African Christian perspective}

This section focuses on the African Christian perspective on the death penalty in Zimbabwe. Given that there are diverse Christian groups in Zimbabwe, this chapter uses the case of Christians from African Independent Churches (AICs), with specific reference to Johane Marange Apostolic Church (JMAC). The JMAC is a Hebraist movement influenced by both the Judeo-Christian tradition and African religion in its beliefs and practices. Its adherents are guided by the Bible on the issue of capital punishment, particularly instances where the Old Testament sets capital punishment as a penalty for certain crimes. For example, the biblical teaching in Genesis 9:6, says: "Whoever sheds the blood of man, by man shall his blood be shed," showing an argument in support of capital punishment. Along the same lines, the Old Testament prescribes death by stoning for various sins (Exodus 21:28), with two witnesses required for the punishment to be carried out.

The JMAC places mitemo iri gumi (the Decalogue) at the centre of its teachings. For instance, in response to the question of what their perspective was on the death penalty, one of the JMAC leaders had this to say: "Mutemo waMozisi unoti usauraya" (The Law of Moses says thou shall not kill, citing Exodus 20:6). This is a biblical teaching is upheld by all members, who therefore find the death penalty to be problematic. In addition, the JMAC refers to similar teachings proclaimed by the Apostle Paul in the New Testament when he denounces retribution for evil. JMAC members referred to where Paul says: "Do not repay evil for evil ... do not take revenge. For it is written 'vengeance is mine says the Lord"' (Romans 12:17-19). Apart from the biblical teaching, the JMAC members were cautious not to kill, because this could invoke the spirit of ngozi. This shows how JMAC members as African Christians combine biblical teachings and African traditional beliefs such as those on ngozi, or avenging spirits.

The crucifixion of Jesus, the result of a death sentence by the Romans for sedition, is a very important event in the theology of JMAC. This is because pasika (Paschal/Passover feast) is a prominent sacrament of the JMAC annual festival gatherings of members from far and wide. Hence, JMAC recognises the passion of Jesus and regards VaJudha (Jews) as blameworthy for the crucifixion of Christ. They hold this view, even though there is scanty constitutional and legal evidence as to why Jesus was executed, and it appears that Jesus was crucified as a political messianic aspirant who wanted to remove the Roman

twins deemed a curse to the community and witchcraft accusations. This was deprivation of life rather than the death penalty per se. 
rule by force. ${ }^{39}$ The crucifixion method was only applied to the Jews, which was perceived to be a Roman way of oppressing the Jews by executing them in a degrading, discriminatory and inhumane method. Whereas JMAC members are theologically inspired and influenced by Old Testament prophets like Moses, Elijah and Elisha, ${ }^{40}$ Stephen, who became the first Christian martyr through death by stoning (Acts 7:54-60) following a death sentence by the Sanhedrin for blasphemy, is also a household name to them. Stephen was accused of challenging the fundamental beliefs of Judaism, including regard for Jerusalem as an unparalleled holy place, affirming the sacredness of the Temple, and following the Mosaic Law. ${ }^{41}$ All the same, the JMAC's position towards the death penalty is negative, because they say only God has the right to take life and that the death penalty is inconsistent with African religious heritage in Zimbabwe. In order to illustrate their preference towards a position of forgiveness and reformation in contrast to the death penalty, the JMAC members quote scriptural texts such as Isaiah 1:18 (KJV), which says: "Come now, and let us reason together, saith the LORD: though your sins be as scarlet, they shall be as white as snow; though they be red like crimson, they shall be as wool." This shows that the JMAC members prefer rehabilitation to the death penalty. Nevertheless, JMAC members have been under the spotlight in Zimbabwe for causing unnecessary deaths of children by failing to comply with conventional medical practices such as immunisation. ${ }^{42}$ The church believes in faith healing and does not allow its members to be treated in hospitals. Therefore, it can be argued that although JMAC is against the death penalty per se, its position on medical issues makes them guilty of violating children's rights in Zimbabwe.

\section{African Islamic perspective}

This section focuses on the Lemba Islamic perspective on the death penalty in Zimbabwe. It particularly focuses on the Lemba Muslims of Sunni disposition belonging to the Karanga ethnic group, located in Chinyika and Hamandishe communities in Gutu District, Masvingo province. Although the Lemba Muslims believe in the efficacy of the Islamic religious law, the sharia law,

39 Brandon SGF. 1967. Jesus and the Zealots: A Study of the Political Factor in Primitive Christianity. New York: Charles Scribner's Sons.

40 See, for example, Sibanda F, Makahamadze T and Maposa RS. 2008. “Hawks and Doves: The Impact of Operation Murambatsvina on Johane Marange Apostolic Church in Zimbabwe", Exchange 37:71.

41 Brown RE. 1997. Introduction to the New Testament. New York: Bloomsburg, 328; Perin N and Duling DC. 1982. The New Testament: An Introduction. London: Harcourt Brace, 320; Kummel G. 1984. Introduction to the New Testament. London: SCM Press, 180.

42 Sibanda F and Marevesa T. 2013. "March or Die? Theological Reflections on the Violation of Children's Rights in African Initiated Churches, Zimbabwe", Asian Academic Research Journal of Multidisciplinary 1(7):163-175. 
which governs the lives of Muslims the world over, ${ }^{43}$ they are also influenced by the context in which they are located. For instance, the Lemba Muslims in Zimbabwe say they are guided by the Constitution of Zimbabwe and find it impossible to apply sharia in its fullness, but at the same time resort to the sharia in their own personal law matters, such as marriage, divorce, inheritance, diet and funeral rites, among other things. ${ }^{44}$ Furthermore, the Lemba Muslims are aware that Islamic punishment, as laid out in the Quran, can often seem very harsh, as indicated by punishments such as the cutting off of the hand of a thief or administering a hundred lashes with a whip for being caught in adultery. ${ }^{45}$ Sharia allows for capital punishment for three offences: murder, adultery and apostasy. ${ }^{46}$ In Islamic states, where some Muslims support capital punishment, they base their views on the fact that it is laid down in sharia, which incorporates the Quranic injunctions, along with the sunna, hadith and other sources. The Lemba Muslims interpret the Quran to understand that forgiveness or mercy is preferable to execution. ${ }^{47}$ In addition, Lemba Muslims refer to the example of the Prophet Muhammad who agreed to capital punishment and used it to sentence people to death for murder when he was ruler of Medina. ${ }^{48}$ However, in Zimbabwe, Lemba Muslims, with their syncretic tendencies that combine Islamic and African traditional religious beliefs, said that they were not comfortable with supporting capital punishment because this could attract ngozi, particularly in the case of the hangman. ${ }^{49}$ This is one of the moderating forces among Lemba Muslims in Zimbabwe. ${ }^{50}$

43 Okon EE. 2014. "Hudud Punishments in Islamic Criminal Law", European Scientific Journal 10(14):227-238.

44 Interview conducted by the authors with a Lemba Imam, Chinyika Community, 20 February 2017.

45 See Surah 5:38 and Surah 24:2 for the punishments administered for theft and fornication, respectively.

46 Among the three categories of criminal behaviour and actions in Islamic jurisprudence, the Hudud offences top the list and are specified in the Quran and sunnah. Hudud crimes include rejection of Islam (apostasy), fornication and theft. Prophet Muhammad is quoted in one of the hadiths as saying: "The blood of a Muslim may not be legally spilt other than in one of three (instances); the married person who commits adultery; a life for a life; and one who forsakes religion (of Islam) and abandons his community." See Okon, "Hudud Punishments in Islamic Criminal Law", 229.

47 Mumisa M. 2015. Sharia Law and the Death Penalty: Would Abolition of the Death Penalty be Unfaithful to the Message of Islam? London: Penal Reform International, 7. Muslims make reference to scriptures suggesting forgiveness and mercy rather than death. For instance, Surah 42:40 states: "Let harm be repaid by an equal harm, though anyone who forgives and puts things right will have his reward from God himself - He does not like those who do wrong."

48 Okon, "Hudud Punishments in Islamic Criminal Law".

49 Interview conducted by the authors with Hasane, a Lemba Elder, Hamandishe Community, 21 February 2017.

50 Another limiting factor when dealing with criminal offences among Lemba Muslims in Zimbabwe, which is a non-Islamic state, is the nonexistence of a sharia court that can handle capital sentences. See Okon, "Hudud Punishments in Islamic Criminal Law", 233, where Okon observes: "Life is sacred and cannot 
The Lemba Muslims of Zimbabwe also point out that saving life as much as possible was better than destroying it. They interpret the Quran as only suggesting capital punishment, not making it compulsory. The Lemba Muslims also stress that if the court of law sentences the accused to death, perhaps after being convicted of murder, the family of the accused should seek forgiveness or pardon from the family of the murdered victim, so that they may pay compensation or "blood money" to avoid the death penalty. In this sense, Lemba Muslims are not against customary law, which is safeguarded by chiefs and elders who arbitrate cases in which restitution is paid. In these ways, the Lemba Muslims and others are resolutely opposed to the death penalty and prefer punishment based on forgiveness, deterrence and reform in ways that are also Afrocentrically sound. This makes the Lemba Muslims more moderate in their perspective towards the use of criminal punishments than Muslims in Islamic states. ${ }^{51}$

\section{THE LEGALITY OF THE DEATH PENALTY IN ZIMBABWE}

Among the Shona people and in the context of Shona traditional religion, the first people to face the death penalty were Sekuru Kaguvi and Mbuya Nehanda after the First Chimurenga War (1896-7) through the ruling of the colonial administrators. They were charged for sedition and causing political mayhem in the country by leading the resistance of the Shona people in Mashonaland..$^{52}$ It is said that before they were hanged, the two were asked to confess their sins in the name of Jesus Christ. Whereas Mbuya Nehanda refused, Sekuru Kaguvi accepted Jesus as His Saviour, got baptised and was accorded a Christian name. Paradoxically, the two were ultimately executed by the colonial administrators, under the same charge, which dismisses the efficacy of Christian baptism in the case of Sekuru Kaguvi. ${ }^{53}$ Thus, it continues to be asked: How legal was this execution, after all?

During the Second Chimurenga War (1965-1980), the colonial system continued to effect capital punishment, particularly on Africans, for political reasons. Many Africans were imprisoned and sentenced to death for various crimes. The existence of capital punishment in the colonial period is confirmed by the

be taken except through a death sentence handed down by a Shariah court of competent jurisdiction in an Islamic state."

51 The moderate stance of Lemba Muslims in Zimbabwe towards the death penalty is reminiscent of the transformation from the harsher side of Islamic law registered in Nigeria in recent years as reported by the New York Times. See Polgreen L. 2007. "Nigeria Turns from Harsher Side of Islamic Law", The New York Times, 1 December.

52 Beach DN. 1986. War and Politics in Zimbabwe. Gweru: Mambo Press.

53 The fact that Sekuru Kaguvi was executed in spite of having been converted to the coloniser's religion seems to suggest a contradiction in the Christian religion of the colonisers - almost a sacrilegious perversion of Christ on the Cross and hardly consistent with forgiveness and redemption, for which Christianity often professes to stand. 
experience of the vice president of Zimbabwe, Emmerson Mnangagwa, who escaped the death penalty by a whisker under the Ian Smith regime due to being underage. ${ }^{54}$ As a young political activist of 21 years, he had been sentenced to death by hanging. The Catholic priest and Shona fiction literary artist, Father Emmanuel Ribeiro, who was a prison chaplain at that time, saved Mnangagwa after he recommended a medical examination to ascertain that he was under the age of 21. During the colonial period, capital punishment could only be handed down to convicts above the age of 21, and it was originally only applied to nine crimes, which were reduced to treason and murder in postcolonial Zimbabwe. ${ }^{55}$ Through his personal experience, Emmerson Mnangagwa is in the forefront of strongly advocating against the death penalty to the extent of proposing the amendment of the Constitution of Zimbabwe. On this basis, it can be argued that the exoneration of some people from the death penalty is a positive development that must be extended to all people in Zimbabwe. ${ }^{56}$

In interviews conducted with traditional leaders, such as chiefs and elders, the majority of respondents felt that the death penalty had outlived its relevance in Zimbabwe. According to the President of the Chiefs' Council in Zimbabwe, Chief Fortune Charumbira, the death penalty was alien to Zimbabwean culture and was a legacy of colonialists. ${ }^{57}$ Chief Charumbira added that capital punishment must be abolished, because executing a person created more harm than good. This is because under the Shona traditional religion, killing was wrong as it could invoke ngozi and create a cycle of violence. ${ }^{58}$ Elsewhere, Chief Charumbira was quoted as saying that when one kills a person, one kills the physical body,

54 Maodza, "Capital Punishment Archaic: VP Mnangagwa”, 2. See also, for example, Muzulu P. 2016. "Mnangagwa Stance on Death Penalty Influenced by Experiences", News Day, 8 February:6.

55 Muzulu, "Mnangagwa Stance on Death Penalty Influenced by Experiences", 6.

56 The reality of equity alongside equality in the issue of the death penalty must be acknowledged in Zimbabwe. In most common law jurisdictions, strict equality is tempered by "equity", whereby women and girls are given exceptions in some cases in order to do justice. Exclusion of women from the death penalty can be regarded as an acknowledgement of their lesser power and greater vulnerability in most sectors of society, such that some of their crimes might be out of selfpreservation or self-defence. In addition, the age limits for the death penalties for youth or the aged can be intended to acknowledge the mental frailties of youth or old age.

57 Interview conducted by the authors with Chief Fortune Charumbira, Masvingo, 20 February 2016. Chief Charumbira, a Karanga by descent, stressed the Shona traditional position, which shows that the death penalty was nonexistent. Hence, it is a discrepancy to have it in the Constitution of the country long after colonialism.

58 Interview conducted by the authors with Chief Fortune Charumbira. The cycle of violence from a Shona perspective hinges on the fact that without proper restitution, ngozi can torment and wipe out families of the perpetrator of murder. See, for example, Sibanda, "Avenging Spirits and the Vitality of African Traditional Law, Customs and Religion in Contemporary Zimbabwe", where there are illustrations of the havoc that ngozi spirits can make when not fully restituted. 
but the spirit of the dead lives on. That is why, in Shona traditional religion and culture, a person who kills someone is made to pay compensation to appease the ngozi spirits. ${ }^{59}$ The chiefs felt that no sane person should accept the job of a hangman, ${ }^{60}$ which has not been filled since 2004 in Zimbabwe. ${ }^{61}$ Along the same lines, another traditional practitioner, Sekuru Friday Chisanyu, the President of the Zimbabwe National Practitioners Association (ZINPA), said Zimbabweans are not keen to take up the job of a hangman for cultural reasons, particularly the teachings of African traditional religion against the shedding of human blood. ${ }^{62}$ In the words of Sekuru Chisanyu, as presented by local media reporter, "In the indigenous African tradition, the death penalty is forbidden. The hangman will surely attract the wrath of the avenging spirits of those that he would have executed. It is for the simple reason that Zimbabweans are shunning this post." ${ }^{63}$ On the whole, most of the traditional leaders and elders interviewed took an abolitionist stance towards the death penalty and proposed that sentences of life in prison for those convicted of serious crimes would be inconsistent with African traditional religious perspectives. ${ }^{64}$

In African Christian circles, church deacons, priests and other church elders of the Johane Marange Apostolic Church who were interviewed denounced the death penalty on the basis of its cruelty to human life, which is God-given. In addition, the church elders cited the dreaded question of ngozi as a vital retributive and deterring factors against supporting the death penalty. This JMAC position on the death penalty is comparable to that of Pastor Emmerson Fundira of Jehovah Sharma Ministries, ${ }^{65}$ who emphasised the same idea when he said that the "Bible is clear on this one - it instructs us not to kill. There is no reason why a human being should take the life of another human being". ${ }^{66}$ This statement represents the abolitionist position held by the majority of the African Initiated Church (AIC) Christians interviewed for this study.

59 Agere, "Death Penalty Raises Stink".

60 This view from the Chief about ngozi and the long absence of a hangman in Zimbabwe may appear simplistic to outsiders, but it forms part of the strong beliefs among the Shona people.

61 Prisoners under death sentence were last hanged in 2004. Zimbabwe's last hangman left the post in 2005 after hanging two notorious armed criminals, Edgar Masendeke and Stephen Chidhumo. See Matabvu D. 2016. "Dying to land hangman's post", The Sunday Mail, 1 May:3.

62 Interview conducted by the authors with Sekuru Friday Chisanyu, Harare, 25 February 2016.

63 See Chara T. 2016. "Hangman holding the aces", The Sunday Mail Extra, 24 January:E1.

64 The African traditional perspectives on preference for life imprisonment mirror the existing teleological theories in African culture for punishment. These include punishing for retribution, deterrence and rehabilitation, as in many Western contexts.

65 This is a Pentecostal church in Zimbabwe, which believes in the preservation of life by all means necessary, including through performing healing miracles and avoiding the death penalty.

66 Chara, "Hangman holding the aces". 
In a similar vein, in 1993, the Catholic Commission for Justice and Peace (CCJP) in Zimbabwe petitioned on behalf of four inmates who had been on the death row for about five years and were soon to be executed. Citing Christian values, the CCJP argued that execution after a prolonged detention on death row was a cruel, inhuman and degrading treatment that contradicted Section 15(1) of the Constitution. ${ }^{67}$ Thus, the JMAC, the Roman Catholic Church and other African Christians recognise the duty of the government in protecting society from crime and the punishing of those who breached the law. Nevertheless, they argue that the aim of the punishment was not supposed to be retributive, but to reform and rehabilitate the offender. On this basis, they have asserted that even the most depraved person has the potential of being reformed through systems of confinement and imprisonment organised by the state. As African Christians, they believe in the sanctity of life, such that only God has the right to take life. In this light, the death penalty is inconsistent with African religious values.

The Lemba Islamic perspective on the death penalty in Zimbabwe is also related to the preceding African religious voices covered by the chapter. Unlike the situation in Islamic states in North Africa, where the death penalty continues to be employed with various degrees of enthusiasm, ${ }^{68}$ the Lemba Muslim participants in Zimbabwe tended to side more with the abolitionists than with the retentionists. Muslim adherents form about 2\% of Zimbabwe's 15 million people. ${ }^{69}$ This partly explains why they are often overshadowed by African Christians and African traditional religions in Zimbabwe. Most Lemba Muslims prefer the use of life imprisonment and payment of compensation by the murderer over capital punishment. ${ }^{70}$ The majority of Lemba Muslim interviewees in this study stressed that today most people throughout the world have a wrong perception about Islam as a religion of violence, but they do not see capital punishment as mandatory from their reading of the Quran. For example, the Quran states: "Take not life, which God has made sacred, except by way of justice and law. Thus does He command you, so that you may learn wisdom" (Quran 6:151). The Lemba Muslims in Zimbabwe would prefer a constitutional amendment to do away with capital punishment in favour of life imprisonment. In their tradition, too, preference for life imprisonment is partly anchored in the belief in the avenging spirit, and it brings an opportunity for rehabilitation to the offender and promotes human dignity as much as possible.

67 Schabas WA. 1997. "African Perspectives on Abolition of the Death Penalty", in Schabas WA (ed). The International Sourcebook on Capital Punishment. Boston: Northeastern University Press, 30-65, 37. See also Constitution of Zimbabwe Amendment (No.13) Act 1993, where Article 15(1) provided that "No person shall be subjected to torture or to inhuman or degrading punishment or other such treatment". See also, for example, Chenwi LM. 2007. Towards the Abolition of the Death Penalty in Africa: A Human Rights Perspective. Pretoria: Pretoria University Law Press, 108.

68 Schabas, "African Perspectives on Abolition of the Death Penalty", 32.

69 Jamal P. 2015. "Muslims Spread into Zimbabwe", New Zimbabwe, 8 February.

70 Interview conducted by the authors with Sadiki, Lemba Elder, Chinyika, Gutu (Masvingo), 21 February 2016. 
The option for life imprisonment resonates with the views of inmates on death row in Zimbabwe, who have petitioned for a life imprisonment because they said the death penalty was inhumane and degrading and unconstitutional. ${ }^{71}$ In this way, the Lemba Muslim views are consistent with those of other religions such as African Christianity and Shona traditional religion in Zimbabwe pertaining to the abolitionist stance.

\section{IS THE DEATH PENALTY CONSISTENT WITH AFRICAN RELIGIOUS HERITAGE?: CRITICAL REFLECTIONS}

From the perceptions of the various religious traditions, legal and secular players on the question of the consistency of capital punishment in light of African religious heritage, a number of reflections can be made. From a purely legal perspective, Section 48 of the Constitution of Zimbabwe can be regarded as a well-drafted provision, because it paves the way for the abolition of the death penalty without saying so expressly. For instance, the court may still opt not to impose the death penalty, even if the murder in question was committed in aggravating circumstances. In fact, a moratorium in Zimbabwe has resulted in the absence death sentences and of hangmen, as no person has been executed since $2004 .{ }^{72}$ Even so, it can be asked: How significant has the moratorium and other policies by government not to pursue the death penalty been for the past decade in Zimbabwe? Why has the government adopted a soft policy on the death penalty? Does the government's action in any way reflect the death penalty's inconsistency with African religious heritage in Zimbabwe?

Responses to the foregoing questions constitute some of the critical reflections attempted here. From a legal front, Zimbabwe is one of the countries in Southern Africa categorised as retentionist for retaining the death penalty, which remained the law even after the colonial period. ${ }^{73}$ Even so, the moratorium on executions has been a positive policy on the death penalty in Zimbabwe since 2004. As a result of the moratorium, Zimbabwe is a state that is in between abolition and retention when it comes to the death penalty. The

71 Muzulu P. 2016. "Death Penalty Challenged", News Day, 14 September.

72 In Zimbabwe, the moratorium has gained momentum due to the life histories of government ministers such as Vice President Emmerson Mnangagwa, who escaped the hangman's noose by a whisker because of being under age, as noted above. In addition, Emmerson Mnangagwa, a lawyer by training, is the Minister of Justice, Legal and Parliamentary Affairs in Zimbabwe. Of late, Zimbabwe has also been criticised for lawlessness at the backdrop of the Land Reform Programme and could be reforming its stance to be in sync with contemporary human rights trends. In addition, the Christian churches, through platforms like the Zimbabwe Catholic Bishops Conference, Evangelical Fellowship of Zimbabwe, and the Zimbabwe Council of Churches, have exerted pressure on government to respect human rights. These could be the circumstances surrounding the adoption of the moratorium.

73 ACHPR, Study on the Question of the Death Penalty in Africa, 25; Schabas, "African Perspectives on Abolition of the Death Penalty", 33. 
disadvantage of a moratorium is that Zimbabwe may resume executions any time. This suggests that Zimbabwe has a hesitant and half-hearted approach to the abolition of the practice. Nevertheless, it is important to consider that the government's soft stance on the death penalty came about because the vice president of Zimbabwe, Emmerson Mnangagwa, spoke about the death sentence from personal experience. In addition, Mnangagwa is currently both Vice President and the Minister of Legal and Parliamentary Affairs and has influence in policy formulations in Zimbabwe. Further important to note is the fact that most legislators in government, besides being advocates for the reclamation of African identity and heritage, are also active Christians from various denominations who attended missionary education. Therefore, this has influenced the Zimbabwean government to take African religious heritage seriously in matters that affect human dignity, such as capital punishment.

Whereas the policy considerations noted above are significant, one of the interesting positive elements on capital punishment is its selective application by age and gender. Instead of it being regarded as a constitutional flaw for exempting women and males between 18 and 21 years, as well as those above 70, it can be argued that the government needs to extend this "olive branch" to all citizens. ${ }^{74}$ This wider application of exemption from the death penalty would be consistent with values within African religious heritage.

On the religious heritage front, important points for reflection exist. As a way of promoting life and shunning bloodshed at all costs, all the three African religious traditions covered in the study teach the idea of reformation and forgiveness. In the Shona traditional religion, for instance, the concept of ubuntu/unhu, anchored on the idea of humanness and communal love, is of pivotal importance in determining the discrepancy between the death penalty and values in the Shona tradition. This Shona perspective forms part of the indigenous African human rights culture, which says a person is a person because of others. The continued mushrooming of death row numbers ${ }^{75}$ and absence of a hangman have been interpreted from an Afrocentric perspective

74 "A child under 10 years old is considered too young to understand that what they are doing is a crime and so cannot be convicted of a criminal offence (unless it can be proven that they fully realised what they were doing was wrong)." In the British law, this is called doli incapax, which means "incapable of wrong doing". So, it becomes very positive for the Zimbabwean Constitution to exempt the 18-21 age group as incapable of doing wrong. See Okon, "Hudud Punishments in Islamic Criminal Law".

75 Agere, "Death Penalty Raises Stink". The source says 117 people are waiting to be hanged. Some of the inmates have been on the death row for over 20 years. This has resulted in emotional stress that violates human rights as the condemned prisoners are "the living dead". The expression "the living dead" can be seen in ambivalence. On the one hand, it reveals the demeaning environment of near hopelessness that the inmates endure as they await execution. On the other hand, the phrase reminds one of John S Mbiti's reference to ancestors as the dead who are living in the spiritual realm (Nyikadzimu). The prison conditions place the inmates in "limbo". See Mbiti, African Religions and Philosophy. 
premised on fear of ngozi and respect for human rights that upholds human life at all costs. Similar to the African communitarian system and solidarity, the African Christian faith espoused by JMAC is one based on mutual sharing - "If one member suffers, all suffer with it" (1 Corinthians 12:26). Therefore, theologically speaking, the death penalty "represents the sinful mutilation of the image of God in which human beings are created." ${ }^{\prime 76}$ The same concern was shared by the Lemba Muslims. Hence, as much as possible, life must be preserved, since no one has the right to kill in God's stead.

\section{CONCLUSION}

This chapter concludes that African religious heritage and law can complement each other in resolving the legality of the death penalty in Zimbabwe. By using the religious heritage lens, it can also be concluded that no one has the right to kill except God. The biblical story of Cain and Abel (Genesis 4:1-15) is instructive, as it teaches that revenge is only for God not for humanity. This is a moral foundation for what legal systems should do to overturn the ideology of "an eye for an eye" with a command for reform and forgiveness. As this chapter has demonstrated, the death penalty is inconsistent with African religious heritage and must be abolished both de facto and de jure in Zimbabwe. After all, Section 48(1) of the Constitution of Zimbabwe also recommends against the mandatory death sentence on the rationale that every person has the right to life. This is a legal flaw in the Constitution of Zimbabwe, which needs urgent amendment.

76 Parratt J. 2008. "Christianity, Ethnicity, and Structural Violence: The Northeast India Case", in Kalu OU (ed). Interpreting Contemporary Christianity: Global Processes and Local Identities. Grand Rapids, MI: William B. Eerdmans Publishing Company, 340. 